
Berlag von A. C. Sebald, nümbetg und Reipjig.

\title{
Das Dorftestament.
}

Mit einem erbrechtlichen Fbriss sowie mit Beispielen (Entwürten) aller vorkommenden diesbezìg. licben Cestamentserrichtungen. : s

\author{
Dargefterlt \\ bon \\ Dr. Wilbelm Dennler.
}

Mit einem ausfiubrlichen Sachregister. 80, IV und 103 Seiten, gebunben Mit. 1.50.

Da es häufig vortommt, Daß bei Zeftamentz. erriditungen bie bejtehenben Borjdriften berlegt unb hierburd bie Teftamente ungültig werben, fo mirb biejes Wert namentlich ben \$erren Cemeinbeboritehern und Gntobefikem gute Dienjte leiften. 